\title{
Impact of Changes in China's Forest Sector on Japan and Other Major Countries
}

\author{
Michinaka, T., Tachibana, S., Turner, J.A., \\ Hori, Y. \& Hirano, Y.
}

Keywords: Global Forest Products Model (GFPM), long-term projection, cluster analysis, forest products, China, Japan

Abstract: The objective of this research is to analyze the impact on the global forest sector of changes in China's domestic market and international trade in forest products. Price and income elasticities of demand for seven forest products are estimated using cluster analysis combined with panel data analysis. Cluster analysis is used to group countries by their levels of per capita gross domestic product (GDP), per capita consumption of forest products and forest coverage rates. Panel data analysis is then undertaken for each cluster, and price and income elasticities for every cluster are estimated. We used the estimated elasticities of demand and other exogenous parameters, including GDP growth, in the Global Forest Products Model (GFPM) to simulate the global forest sector through 2030. The GFPM is a dynamic economic equilibrium model encompassing 180 countries and 14 forest products. The GFPM results show that China is likely to continue to rely on foreign raw materials, leading to increases in consumption in Asia and throughout the world and in prices of forest products. A lower GDP growth for China would lead to lower world consumption of forest products and to lower prices. The GFPM results also show that Japan and South Korea (hereafter Korea) could take advantage of the lower prices to import more raw materials if China were to consume less. Increases in manufacturing costs in

Received August 5, 2010; Accepted December 28, 2010 
China could lead to a significant decrease in consumption in China, to less of an impact in Japan and Korea and to greater consumption and fewer exports in Africa and Oceania.

\section{Introduction}

Since 1999, China has eliminated import tariffs on roundwood, has encouraged more foreign direct investment and exporting, and has witnessed a rapid increase in the consumption of and foreign trade in forest products. China imported 4.82 million $\mathrm{m}^{3}$ of roundwood in 1998 and reached 28.06 million $\mathrm{m}^{3}$ in 2009 (WTA, 2010). China now imports forest products from more countries than in the past and exports to more markets in the world. This change has altered the global picture of the distribution and consumption of forest products. A forest sector outlook can be used to foresee how China's demand will change, how the demand and supply may balance, and how China, Japan and other countries could be affected in a global context.

The objectives of our research are to simulate the global forest sector through 2030 under three scenarios and to analyze the impact on the global forest sector of changes in China's domestic market and in international trade of forest products using the Global Forest Products Model (GFPM), a dynamic economic equilibrium model encompassing 180 countries and 14 forest products (Buongiorno et al., 2003). The GFPM predicts future trends in consumption, production, imports, exports, and prices of forest products and forest resources. The GFPM has previously been applied to the analysis of a number of issues, such as implications of the Russian roundwood export tax increase (Turner et al., 2008), illegal logging (Li et al., 2008), and the global outlook for woods and forests with bioenergy demands under the two scenarios of IPCC (Intergovernmental Panel on Climate Change) (Raunikar et al., 2010). 
In our research, the main sources of our data are the Food and Agriculture Organization (FAO, 2010), the World Bank (2009), and the US Energy Information Administration (U. S. EIA, 2010). The GFPM software and data set are from Prof. Joseph Buongiorno's homepage for the GFPM (2010). Demand elasticities for seven end-use forest products were estimated using cluster analysis combined with panel data analysis. Some other exogenous parameters were also changed to meet the needs of our research objectives.

\section{Materials and methods}

Buongiorno et al. (2003) give the basic mathematical specification and some applications for the GFPM. The GFPM has been improved since its use in 1998 for the FAO's long-term projections of forest products consumption, production and trade (Zhu et al., 1997); one such improvement is the inclusion of predictions of changes in forest area and growing stock (Turner et al., 2006), as described by Zhu et al. (2010).

The GFPM simulates market equilibrium by means of quadratic programming, based on the theory of spatial equilibrium in competitive markets (Samuelson, 1952). The objective function is set to maximize the social surplus, or the sum of the producer and consumer surpluses, the value of final product demand minus the cost of production and transportation, subject to the material balance and capacity constraints in each country or region and in each year (Zhu et al., 2010):

$$
\begin{aligned}
\text { [1] } \operatorname{Max} Z= & \sum_{i} \sum_{k} \int_{0}^{D_{i k}} P_{i k}\left(D_{i k}\right) d D_{i k}-\sum_{i} \sum_{k} \int_{0}^{S_{i k}} P_{i k}\left(S_{i k}\right) d S_{i k} \\
& -\sum_{i} \sum_{k} \int_{0}^{Y_{i k}} m_{i k}\left(Y_{i k}\right) d Y_{i k}-\sum_{i} \sum_{j} \sum_{k} c_{i j k} T_{i j k},
\end{aligned}
$$


where the subscripts $i$ and $j$ stand for countries, $k$ for product, $P$ for price in US dollars of constant value, $D$ for final product demand, $S$ for raw material supply, $Y$ for quantity manufactured, $m$ for manufacturing cost, $T$ for quantity transported, and $c$ for cost of transportation, including tariffs and taxes. All variables refer to a specific year.

The essential constraint for this mathematical programming problem is the material balance, requiring that, in each country $(i)$ and for each commodity $(k)$, the sum of the quantity imported ( $j$ to $i$ ), supplied as raw material and manufactured, must be equal to the sum of the domestic demand as an end product, the quantity used in the manufacturing of other commodities $(n)$ as an input, and the exports ( $i$ to $j)$.

$$
\text { [2] } \quad \sum_{j} T_{j i k}+S_{i k}+Y_{i k}=D_{i k}+\sum_{\mathrm{n}} a_{i k n} Y_{i n}+\sum T_{i j k}, \quad \forall_{i}, k,
$$

where $a_{i k n}$ is the input of product $k$ per unit of product $n$.

In the GFPM, the final demand and the raw material supply are represented by econometric equations, where demand elasticities of GDP and price and supply elasticities of price and shifters, such as per capita GDP, forest stock and forest area, are estimated exogenously. The final demand and the raw material supply are linked by input-output coefficients. The model of forest resources was developed by Turner et al. (2006), with changes in forest area used in the GFPM as an exogenous parameter. Manufacturing costs are estimated as the difference between the price of a product and the cost of the wood and fiber used to manufacture it, under the assumption of zero net profit. The GFPM assumes that every country imports from and exports to the world market. Prices are determined endogenously. Data from 1992 to 2006 are used, while 2006 is taken as a base year. 


\section{Estimating elasticities of demand for forest products with cluster analysis}

Because elasticities of demand for end forest products have an important influence on predictions of demand, elasticities of demand for seven end forest products were estimated in our research (Michinaka et al., 2010). In the GFPM, the end products are fuelwood, other industrial roundwood, sawnwood, plywood, particleboard, fiberboard, newsprint, printing and writing paper, other paper and paperboard. Because of the availability of data, demand elasticities for fuelwood and other industrial roundwood were not estimated. Price and GDP elasticities of demand for sawnwood, plywood, particle board, fiberboard, newsprint, printing and writing paper, and other paper and paperboard were estimated using cluster analysis and panel data analysis (Table 1).

Cluster analysis was introduced to group countries together according to every forest product, using cross-sectional data for per capita GDP, per capita consumption of forest products, and forest coverage. These variables were selected according to microeconomic theory. The application of cluster analysis prior to the estimation of demand elasticities solved the problems of data availability and parameter heterogeneity in the model specification, and it avoided grouping countries arbitrarily. Mean absolute deviation was used for data standardization, and the k-medoids approach and silhouette technique were used in cluster analysis. Statistics of clusters for every forest product showed various combinations of countries with similar levels of per capita GDP and forest coverage and consumption, such as a cluster including countries with high per capita GDP, low forest coverage and high consumption of the assessed forest product. The results of cluster analysis were validated by one-way analysis of variance, but whether their elasticities by panel data analysis are significantly different or not is not tested because the objective of cluster analysis here is to estimate elasticities 
but not to group countries according to their levels of elasticities.

Countries included in the panel data analysis were selected based on time series data availability and quality. As implied by cluster analysis, countries in the same cluster are similar in variables, such as per capita GDP, forest coverage and consumption level, so the results obtained for some of the countries in the cluster can be used to represent the whole cluster. In this research, long-run static models and short-run and long-run dynamic models were estimated using panel data analysis for countries in each cluster, with data in each cluster from 1992 to 2007 and from 9 to 44 countries. We found that long-run dynamic elasticities were higher than short-run dynamic estimations and that dynamic model estimations were better than static model estimations, as shown in RMSE statistics. Compared with previous research, our results captured the diversity in elasticity estimates and should better reflect producer behavior affected by its own price and output changes because of the cluster analysis. These results were be used in the GFPM for making long-term projections.

\section{Scenarios for the GFPM}

In our projections, three scenarios were established, i.e. the base scenario, alternative scenario 1 and alternative scenario 2 . The base scenario is described as follows. First, for GDP data from 2011 to 2030, US Energy Information Administration (U.S. EIA, 2010) projections were used. The EIA gives three sets of projections: a reference case, a high economic growth case, and a low economic growth case. Considering that the world financial crisis originated in 2008 from the United States, the data set for low economic growth case was adopted. This data set shows that China's GDP growth rates will be $7.74 \%$, $5.89 \%$ and $4.25 \%$ for 2011 to 2015, 2016 to 2020 and 2021 to 2030, respectively. For Japan, they will be $0.28 \%, 0.33 \%$ and $-0.14 \%$ for the 
Table 1. Long-term dynamic elasticities of demand for global forest products

\begin{tabular}{|c|c|c|c|}
\hline $\begin{array}{c}\text { Forest } \\
\text { Products }\end{array}$ & Cluster & Price elasticity & Income elasticity \\
\hline \multirow{7}{*}{$\begin{array}{c}\text { Sawnwood } \\
\text { (170) }\end{array}$} & $1(44)$ & -0.14 & 0.27 \\
\hline & $2(43)$ & -0.12 & 0.98 \\
\hline & $3(34)$ & -0.28 & 0.80 \\
\hline & $4(19)$ & -0.79 & 0.97 \\
\hline & $5(9)$ & -1.63 & 0.73 \\
\hline & $6(10)$ & -0.27 & 1.02 \\
\hline & $7(11)$ & -0.78 & 1.26 \\
\hline \multirow{5}{*}{$\begin{array}{c}\text { Plywood } \\
\text { (118) }\end{array}$} & $1(25)$ & -0.79 & 0.96 \\
\hline & $2(34)$ & -0.73 & 1.00 \\
\hline & $3(25)$ & -0.04 & 0.49 \\
\hline & $4(25)$ & -1.75 & 0.98 \\
\hline & $5(9)$ & -0.97 & 0.07 \\
\hline \multirow{4}{*}{$\begin{array}{c}\text { Particle } \\
\text { Board (93) }\end{array}$} & $1(30)$ & -0.94 & 1.31 \\
\hline & $2(13)$ & -1.21 & 0.11 \\
\hline & $3(19)$ & -0.03 & 0.60 \\
\hline & $4(31)$ & -0.17 & 1.17 \\
\hline \multirow{4}{*}{$\begin{array}{l}\text { Fiberboard } \\
\text { (111) }\end{array}$} & $1(34)$ & -1.50 & 0.95 \\
\hline & $2(40)$ & -0.50 & 1.00 \\
\hline & $3(22)$ & -0.03 & 1.00 \\
\hline & $4(15)$ & $\begin{array}{l}-0.38 \\
\end{array}$ & 1.04 \\
\hline \multirow{5}{*}{$\begin{array}{l}\text { Newsprint } \\
(105)\end{array}$} & $1(26)$ & -0.24 & 0.84 \\
\hline & $2(16)$ & -0.14 & 1.00 \\
\hline & $3(18)$ & -0.07 & 0.34 \\
\hline & $4(28)$ & -0.11 & 0.95 \\
\hline & $5(17)$ & -0.24 & 0.85 \\
\hline \multirow{5}{*}{$\begin{array}{l}\text { Printing and } \\
\text { Writing } \\
\text { Paper } \\
(122)\end{array}$} & $1(33)$ & -0.62 & 1.41 \\
\hline & $2(22)$ & -0.44 & 1.20 \\
\hline & $3(22)$ & -0.44 & 0.93 \\
\hline & $4(16)$ & -0.91 & 0.09 \\
\hline & $5(29)$ & -0.54 & 1.26 \\
\hline \multirow{5}{*}{$\begin{array}{c}\text { Other Paper } \\
\text { and } \\
\text { Paperboard } \\
(127)\end{array}$} & $1(35)$ & -0.39 & 1.28 \\
\hline & $2(24)$ & -0.86 & 1.14 \\
\hline & $3(22)$ & -0.42 & 1.16 \\
\hline & $4(25)$ & -0.24 & 1.24 \\
\hline & $5(21)$ & -0.15 & 0.65 \\
\hline
\end{tabular}

Note: Numbers in the parentheses in the left column are sizes of the clusters

same periods, and for the whole world, they will be $2.75 \%, 3.26 \%$ and $2.6 \%$. Second, as for China's changes in forest resources, we examined the historical changes in forest resources published by the Chinese government (SFA, 2010) and decided that the annual rate of change of forest area would be $2.26 \%, 1.00 \%, 0.50 \%$ and $0.10 \%$ for 2007 to 2010 , 2011 to 2015,2016 to 2020 , and 2021 to 2030, respectively. At the same time, the annual rate of change in per hectare forest stock would 
be $0.27 \%$ for 2007 to 2010 and $0.01 \%$ for all other periods. Third, the demand elasticities for seven end products were based on our estimates from cluster and panel data analysis. For all other model assumptions, the data set downloaded from the GFPM homepage was used.

For alternative scenario 1, we decreased the annual GDP growth rate for China by 1 percentage point, i.e. new GDP growth rates for China were $6.74 \%, 4.89 \%$ and $3.25 \%$ for 2011 to 2015,2016 to 2020 and 2021 to 2030, respectively. All of the other parameters remained the same.

For alternative scenario 2, China's annual GDP growth rate was decreased by 1 percentage point, and at the same time, manufacturing costs were increased by 1 percentage point annually. In this way, the impact on China, Japan and the world of China's changes in the domestic market and the forest sector could be discussed.

\section{Results}

\subsection{Base scenario results}

Consumption, production, imports, exports, and prices for 14 forest products and forest resources and for 180 countries were simulated through 2030 using the GFPM under the base scenario, alternative scenario 1 and alternative scenario 2 . In the following figures, data for 1992 to 2007 are actual data, while data for 2008 to 2030 are projected data. The base year in the current version of the GFPM is 2006, so data from 2006 were projected even though projected data in 2006 and 2007 are not shown in the figures.

Thus, there are differences between actual data and projected data for 2006 and 2007, but these differences are not errors. The GFPM calibrates and smoothes recent historical FAO data because (1) countryspecific FAO data for production and consumption of products such as industrial roundwood, sawnwood, plywood often are not balanced, i.e. 
the reported consumption of industrial roundwood does not match the countries' reported production of wood products from industrial roundwood; (2) year-to-year FAO data for a country can change considerably, which means that projections for a country can change greatly when the GFPM base year changes. To address these issues, the GFPM data calibration process smoothes the historical FAO data. Use of smoothing also reflects the fact that the GFPM provides long-term information on trends, although it provides less accuracy in year-to-year fluctuations. Finally, the FAO data are calibrated to correct for errors in the data, such as negative apparent consumption, and data from previous years reported in more recent years as up-to-date data have not been provided by these countries to the FAO. The results show that the projected world prices of most forest products would increase; while the price of plywood would increase the fastest, sawnwood would keep its price stable. According to base scenario projections, the world consumption of forest products would continue to increase over the next two decades. It is projected that the consumption of industrial roundwood would increase to 2.7 billion $\mathrm{m}^{3}$ by 2030 from 1.7 billion $\mathrm{m}^{3}$ in 2007 at an annual growth rate of $2 \%$ (Fig.1). World consumption of plywood and fiberboard would increase the fastest, by over $2 \%$ annually, while the consumption of sawnwood and particleboard would increase only slightly, by about 1\% annually. In the last period, from 2026 to 2030, consumption of industrial roundwood would increase faster due to the increase in pulp- and paper-making.

Next, situations for industrial roundwood will be discussed. The projections by region for the trends of consumption of industrial roundwood are shown in Figure 2. Consumption of industrial roundwood would increase in all regions except Africa. North \& Central America would still be the largest consumer of industrial roundwood, while Europe, Asia and South America would follow, and Oceania would surpass 


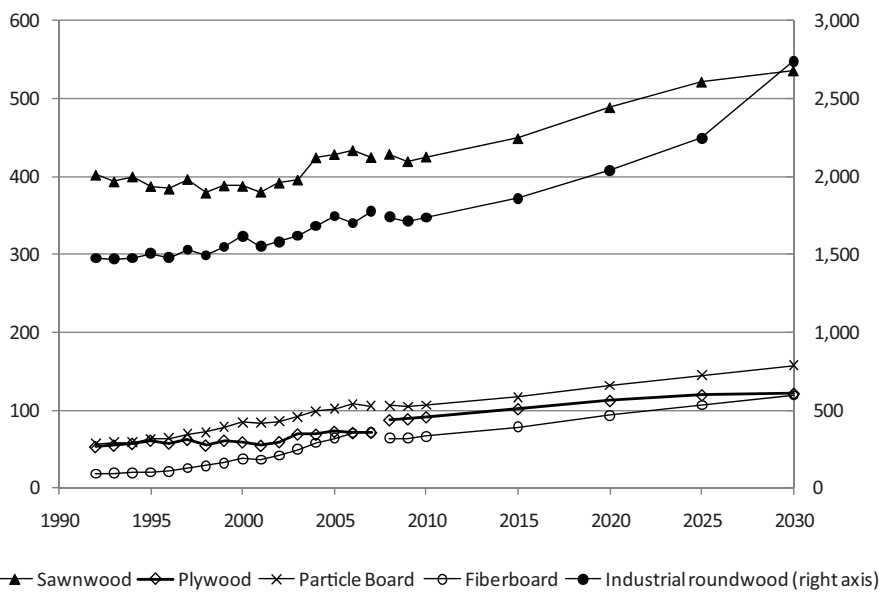

Figure 1. World consumption of some selected forest products

$$
\left(1,000,000 \mathrm{~m}^{3}\right)
$$

Africa. Consumption in South America, Oceania and Asia would increase fastest because of the rapid increases in Brazil, Chile, Australia and China.

The simulations of net trade, i.e. exports minus imports, of industrial roundwood by region are shown in Figure 3. Due to large imports by China, Japan and Korea, Asia would be the only region with negative net trade. Asia would be projected to rely increasingly on imported industrial roundwood, while all of the other regions except Africa would greatly increase their exports of industrial roundwood. Comparing the amounts of consumption and net trade, it can be seen that Europe and North \& Central America would export more while their levels of consumption would keep increasing from 2008 to 2030, and Asia would rely more on imported industrial roundwood over the next two decades.

The projections for the production of industrial roundwood by selected countries are shown in Figure 4. Production of industrial roundwood would increase in all five selected countries. Production of in- 


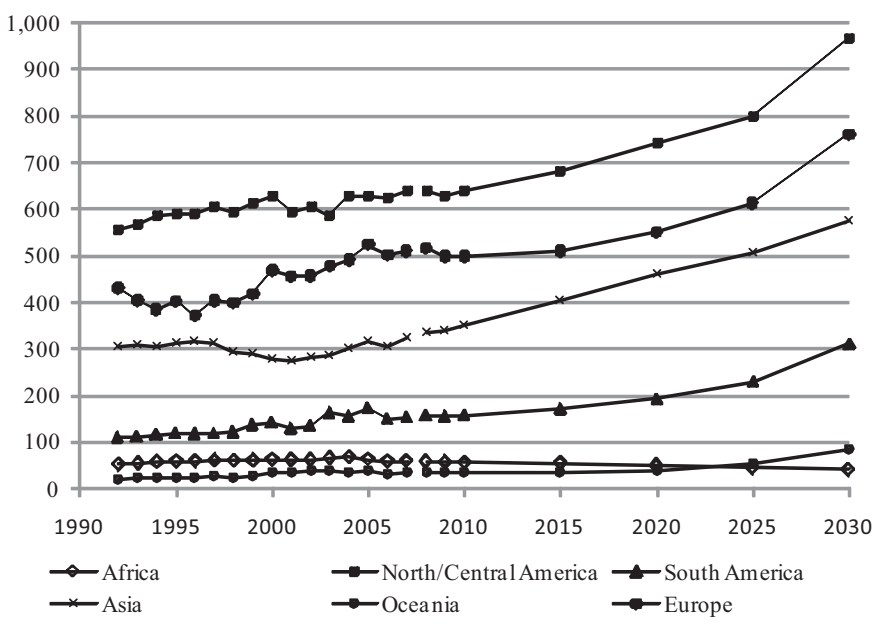

Figure 2. Consumption of industrial roundwood by region

$$
\left(1,000,000 \mathrm{~m}^{3}\right)
$$

dustrial roundwood in Japan would increase the fastest, and Japan's annual production could reach 39 million $\mathrm{m}^{3}$ by 2030. Production of industrial roundwood in the United States, the Russian Federation and Korea would increase at more than $2 \%$ per year, but China's production would increase by less than $2 \%$.

Figure 5 shows the net trade of industrial roundwood for selected countries. China's net trade would jump sharply, showing that China would continue to rely on imported raw materials. As prices increased, Japan would import less and would raise its self-sufficiency rate by taking advantage of its abundant forest resources. The United States would export more roundwood, while Russia would export less due to its industrial policy. When implementing the GFPM, the tariff issue in Russia was considered, and the tariff for exporting roundwood in Russia was set to $20 \%$. 


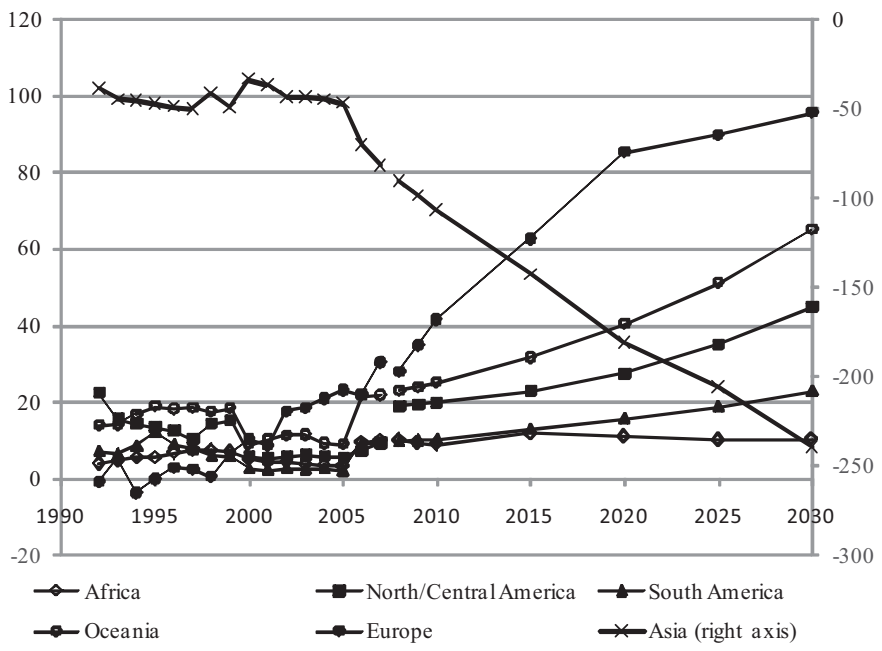

Figure 3. Net trade (exports minus imports) of industrial roundwood by region $\left(1,000,000 \mathrm{~m}^{3}\right)$

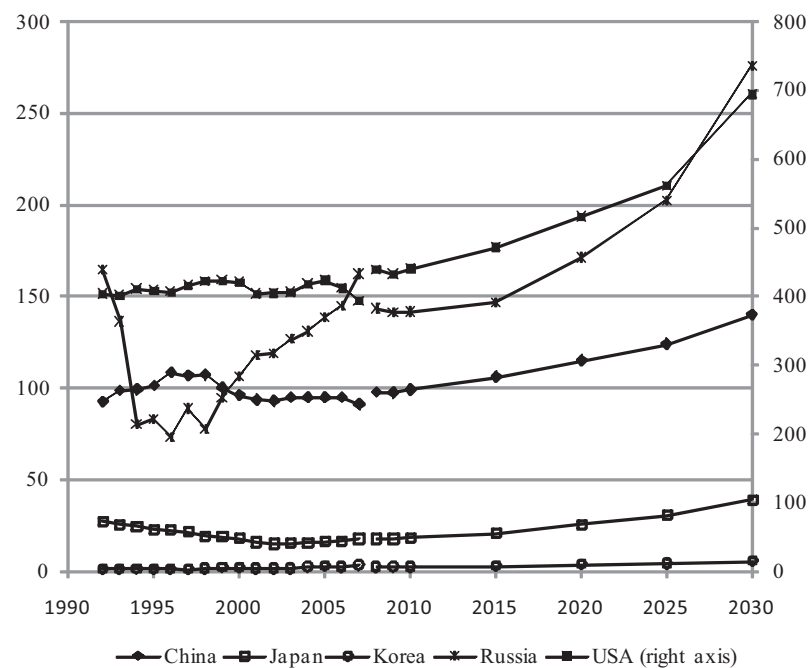

Figure 4. Production of industrial roundwood in selected countries $\left(1,000,000 \mathrm{~m}^{3}\right)$

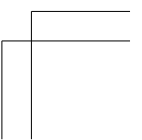




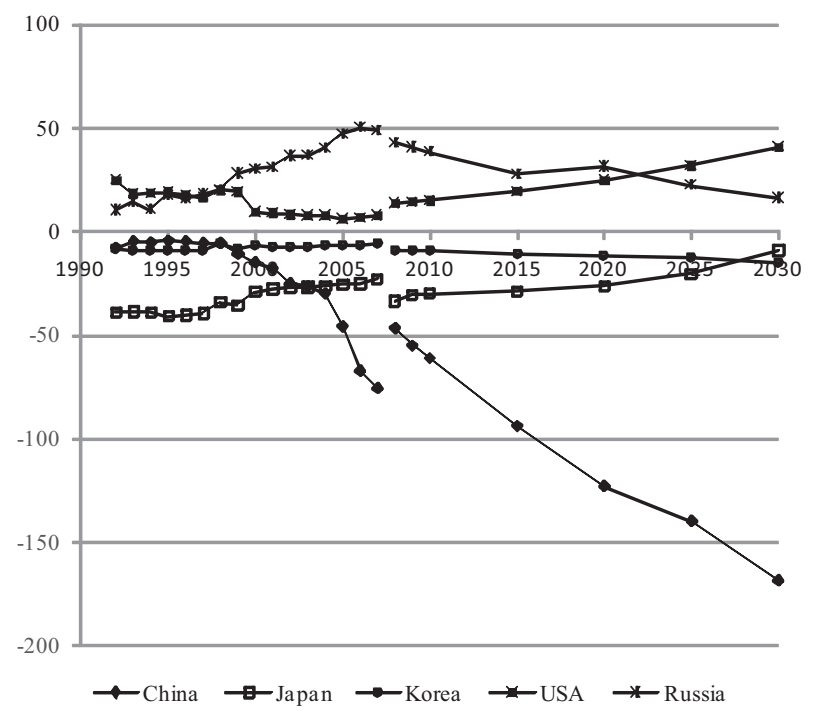

Figure 5. Net trade of industrial roundwood in selected countries

$$
\left(1,000,000 \mathrm{~m}^{3}\right)
$$

\subsection{Alternative scenario results}

To further analyze the impact on Japan and other major countries' forest sectors of changes in China's domestic market and international trade, two alternative scenarios were simulated using the GFPM. We assumed that, in alternative scenario 1, only China's GDP growth rate decreased by 1 percentage point every year, while all other exogenous parameters remained unchanged. In alternative scenario 2, we assumed a 1 percentage point decrease in GDP growth rate and a 1 percentage point increase in manufacturing cost for all manufactured products happening simultaneously. Some of the comparisons are shown in Tables 1 through 5. The projected prices were first checked and compared to the base and alternative scenarios (results using 2006 real value are shown in Tab.2). In the GFPM, for net exporting countries, the price is equal to the average unit value of world exports, and for net importing 
countries, the price is equal to the world average unit export value plus freight cost and tariffs. Therefore, prices for China, Japan and Korea are higher than those for the world average, the United States and the Russian Federation. Table 2 shows that, in both alternative scenarios, the prices would be lower than those in the base scenario because China would not grow as quickly as expected. In 2030, for alternative scenario 1, the price of industrial roundwood in China and the whole world would be $7 \%$ lower, the price in Japan and Korea would be $6 \%$ lower, and the price in the United States and the Russian Federation would be less affected. For alternative scenario 2, the price in the United States would be significantly affected, reflecting the stronger impact of manufacturing cost on forest product production and, thus, the demand for industrial roundwood.

Table 2. Base scenario price and difference between base and alternative scenarios for industrial roundwood for selected countries and the world

\begin{tabular}{|l|rrrr|rrrrrrrrr|}
\hline & \multicolumn{9}{|c|}{ Base scenario $\left(\mathrm{US} \$ \mathrm{~m}^{3}\right)$} & \multicolumn{3}{c|}{ Alternative scenario $1(\%)$} & \multicolumn{3}{c|}{ Alternative scenario $2(\%)$} \\
\cline { 2 - 15 } & 2015 & 2020 & 2025 & 2030 & 2015 & 2020 & 2025 & 2030 & 2015 & 2020 & 2025 & 2030 \\
\hline China & 94 & 106 & 117 & 138 & -1 & -3 & -5 & -7 & -2 & -3 & -4 & -8 \\
Japan & 98 & 111 & 123 & 145 & -1 & -2 & -4 & -6 & -1 & -3 & -3 & -6 \\
Korea & 99 & 111 & 123 & 145 & -1 & -2 & -4 & -6 & -1 & -3 & -3 & -6 \\
USA & 80 & 88 & 96 & 123 & 0 & -1 & -2 & -3 & 0 & -1 & -1 & -8 \\
Russia & 73 & 81 & 92 & 122 & 0 & -3 & -5 & -2 & 0 & -3 & -4 & -1 \\
World & 85 & 98 & 110 & 133 & -1 & -3 & -4 & -7 & -2 & -3 & -3 & -7 \\
\hline
\end{tabular}




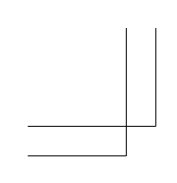

Impact of Changes in China's Forest Sector on Japan and Other Countries

209
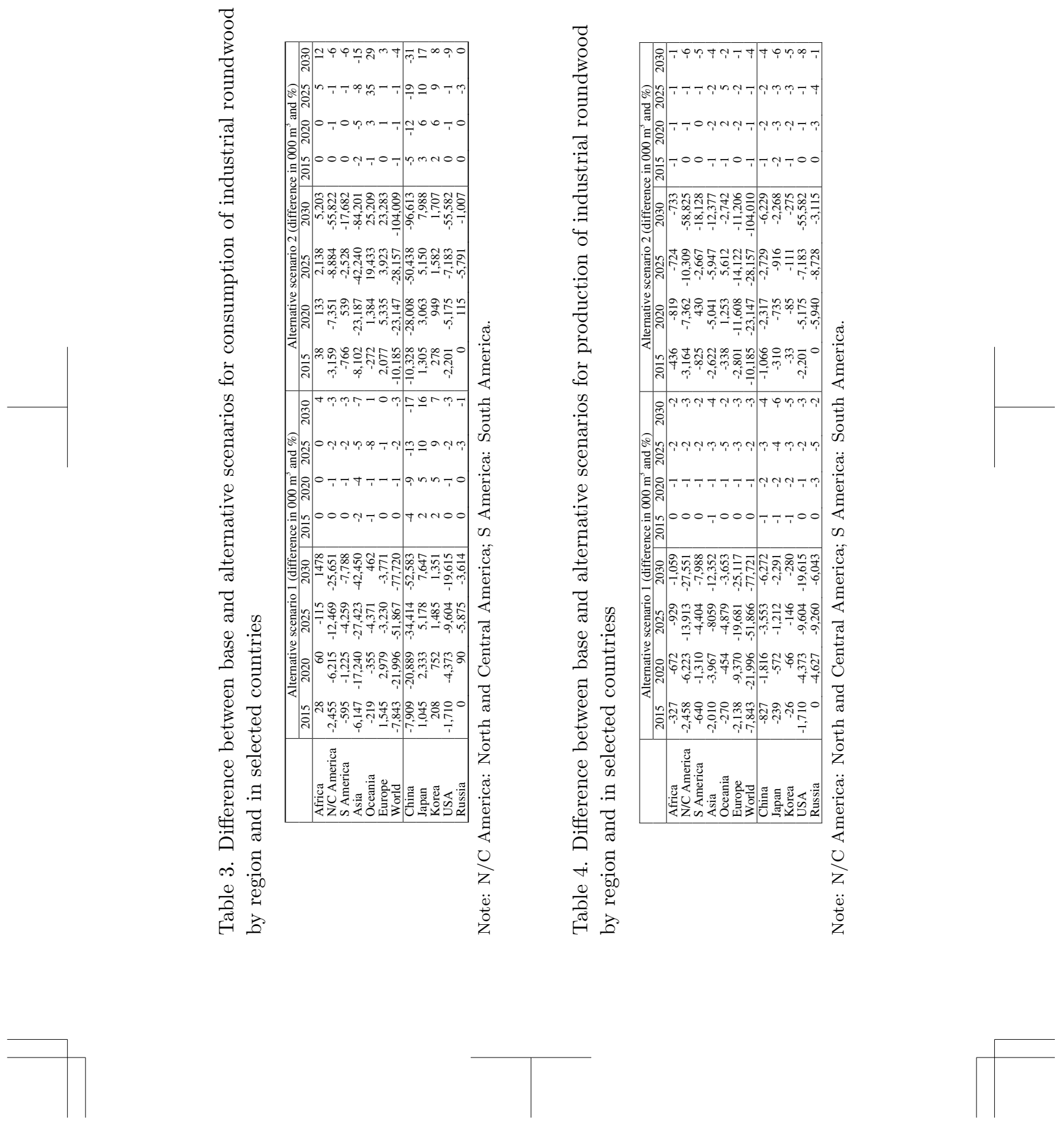
World consumption of industrial roundwood would decrease by $3 \%$ if China's economy were to grow more slowly. In this case, China's consumption would be $17 \%$ lower by 2030 , Japan's consumption would be $16 \%$ higher, and Korea's consumption would be $7 \%$ higher. Consumption by the United States and the Russian Federation would be less affected. Of course, Asia would be more affected because of China's decrease. If China's manufacturing cost increased by 1 percentage point at the same time that its GDP growth decreased, China would suffer a significant decrease in its industrial roundwood consumption, to $31 \%$ by 2030 . Japan and Korea would not increase their consumptions due to China's cost increase, but consumption in Africa and Oceania would increase due to China's decreased consumption. Because the world price would decrease and the demand from China would not be strong, it would be much easier for Africa and Oceania to consume more wood, although the production in Africa and Oceania would not be significantly affected.

The impact of the two alternative scenarios on the production of industrial roundwood is shown in Table 4. World production would be $3 \%$ lower by 2030, China's production would be $4 \%$ lower, Japan's $6 \%$ lower and Korea's $5 \%$ lower. If the manufacturing cost in China increased at the same time as the economy grew more slowly, then the production of industrial roundwood in North and Central America and South America would be $6 \%$ and $5 \%$ lower, respectively.

China would import less industrial roundwood in alternative scenario 1 than it does in the base scenario, and it would import considerably less in alternative scenario 2 due to the sharp decrease in consumption. In both of these alternative scenarios, Japan would increase its imports of industrial roundwood by as much as twice the amount in the base scenario. If the world price decreased, Japan would consume more industrial roundwood in the alternative scenarios than it would in the 
base scenario. This increase in consumption would come as a result of a lower world price, making imports comparatively cheaper than domestic harvests. Japan's domestic production would be affected by lower prices of imported raw materials. With a lower world price, Africa and Oceania would increase their consumption and would decrease their exports. It is interesting that the United States' net-trade would not be affected even though its price would decrease as much as China's. It appears that the United States would be able to maintain its trade level by lowering its price and increasing exports to Japan and other countries.

Table 5. Difference between base and alternative scenarios for net trade of industrial roundwood by region and in selected countries

\begin{tabular}{|c|c|c|c|c|c|c|c|c|}
\hline & \multicolumn{8}{|c|}{ Alternative scenario 1 (difference in $000 \mathrm{~m}^{3}$ and $\%$ ) } \\
\hline & 2015 & 2020 & 2025 & 2030 & 2015 & 2020 & 2025 & 2030 \\
\hline Africa & -355 & -732 & -815 & $-2,538$ & -3 & -7 & -8 & -25 \\
\hline N/C America & -3 & -7 & $-1,444$ & $-1,899$ & 0 & 0 & -4 & -4 \\
\hline S America & -46 & -85 & -145 & -200 & 0 & -1 & -1 & -1 \\
\hline Asia & 4,137 & 13,273 & 19,364 & 30,099 & -3 & -7 & -9 & -13 \\
\hline Oceania & -51 & -99 & -508 & $-4,115$ & 0 & 0 & -1 & -6 \\
\hline Europe & $-3,683$ & $-12,349$ & $-16,451$ & $-21,347$ & -6 & -14 & -18 & -22 \\
\hline China & 7,082 & 19,074 & 30,861 & 46,311 & -8 & -15 & -22 & -27 \\
\hline Japan & $-1,284$ & $-2,905$ & $-6,390$ & $-9,939$ & 4 & 11 & 31 & 111 \\
\hline Korea & -233 & -818 & $-1,631$ & $-1,631$ & 2 & 7 & 13 & 11 \\
\hline USA & 0 & 0 & 0 & 0 & 0 & 0 & 0 & 0 \\
\hline \multirow[t]{3}{*}{ Russia } & 0 & $-4,717$ & $-3,385$ & $-2,429$ & 0 & -15 & -15 & -15 \\
\hline & \multicolumn{8}{|c|}{ Alternative scenario 2 (difference in $000 \mathrm{~m}^{3}$ and $\%$ ) } \\
\hline & 2015 & 2020 & 2025 & 2030 & 2015 & 2020 & 2025 & 2030 \\
\hline Africa & -473 & -952 & $-2,862$ & $-5,936$ & -4 & -9 & -28 & -58 \\
\hline N/C America & -5 & -11 & $-1,426$ & $-3,004$ & 0 & 0 & -4 & -7 \\
\hline S America & -59 & -109 & -139 & -447 & 0 & -1 & -1 & -2 \\
\hline Asia & 5,481 & 18,146 & 36,293 & 71,824 & -4 & -10 & -18 & -30 \\
\hline Oceania & -67 & -131 & $-13,821$ & $-27,950$ & 0 & 0 & -27 & -43 \\
\hline Europe & $-4,878$ & $-16,943$ & $-18,045$ & $-34,488$ & -8 & -20 & -20 & -36 \\
\hline China & 9,263 & 25,692 & 47,709 & 90,384 & -10 & -21 & -34 & -54 \\
\hline Japan & $-1,615$ & $-3,798$ & $-6,066$ & $-10,255$ & 6 & 15 & 30 & 115 \\
\hline Korea & -311 & $-1,033$ & $-1,693$ & $-1,982$ & 3 & 9 & 13 & 13 \\
\hline USA & 0 & 0 & 0 & 0 & 0 & 0 & 0 & 0 \\
\hline Russia & 0 & $-6,055$ & $-2,938$ & $-2,108$ & 0 & -19 & -13 & -13 \\
\hline
\end{tabular}

Note: N/C America: North and Central America; S America: South America.

Finally, the impact in percentages of consumption, production, net trade and prices of sawnwood, plywood, particleboard and fiberboard on the alternative scenarios for China and Japan is shown in Table 6 . 
Compared to the base scenario, China's consumption and production would be negatively affected by the lower GDP growth rate and higher manufacturing costs, but Japan's consumption would remain stable or increase slightly, if not to the same extent, due to lower forest product prices. In addition, Japan's production would remain stable or increase slightly because of the slight increase in consumption. The results also show that China would import less sawnwood and plywood if it consumed less, but if the manufacturing cost increased, then China would import more due to the decreased competitiveness of its domestic production. If Japan manufactured more in these two scenarios, Japan would import fewer materials, particularly plywood. China and Japan's net trade of particleboard and fiberboard would be little affected, except for Japan's fiberboard net imports, which would be lower. As for price, the prices in China would increase in alternative scenario 2, except for plywood, due to the higher cost of manufacture, in which decreased consumption would play a more significant role. With all of these selected forest products, prices in Japan would decrease due to China's lower consumption.

\section{Discussion}

With the forecast of GDP growth rate sourced from the EIA and the theory of spatial equilibrium in competitive markets, by way of the GFPM and based on the mathematical programming, we simulated the forest sector through 2030. It was found that the world trend of increases in consumption, production and trade would continue. The general trend for the world would be similar to that reported in FAO (2009), which follows the historical trends. For Africa, however, stronger growth in consumption and production of industrial roundwood and sawnwood is expected in FAO (2009) than in this research. GFPM projections of the lower level of roundwood production 
Table 6. Difference between base and alternative scenarios for consumption, production, net trade and price for selected products

\begin{tabular}{|c|c|c|c|c|c|c|c|c|c|}
\hline & \multicolumn{4}{|c|}{ Alternative scenario $1(\%)$} & \multicolumn{4}{|c|}{ Alternative scenario $2(\%)$} \\
\hline & & 2015 & 2020 & \multicolumn{2}{|c|}{$2025 \quad 2030$} & \multirow[t]{2}{*}{2015} & \multirow[t]{2}{*}{2020} & \multirow{2}{*}{2025} & \multirow[t]{2}{*}{2030} \\
\hline \multirow{12}{*}{ Sawnwood } & \multicolumn{5}{|c|}{ Consumption } & & & & \\
\hline & China & -3 & -5 & -8 & -11 & \multirow{2}{*}{$\begin{array}{r}-3 \\
0\end{array}$} & \multirow{2}{*}{$\begin{array}{r}-6 \\
1\end{array}$} & \multirow{3}{*}{$\begin{array}{r}-9 \\
1\end{array}$} & \multirow{3}{*}{$\begin{array}{r}-11 \\
2\end{array}$} \\
\hline & Japan & 0 & 1 & 1 & 2 & & & & \\
\hline & \multicolumn{2}{|c|}{ Production } & & & & & & & \\
\hline & China & -5 & -6 & 5 & -6 & -5 & -10 & -18 & -54 \\
\hline & \multirow{2}{*}{\multicolumn{2}{|c|}{$\begin{array}{l}\text { Japan } \\
\text { Net trade }\end{array}$}} & 3 & 3 & 4 & 4 & 4 & 3 & 4 \\
\hline & & & & & & & & & \\
\hline & China & 0 & -5 & -21 & -21 & 0 & 0 & 0 & 78 \\
\hline & Japan & -8 & -8 & -8 & -8 & -10 & -10 & -10 & -10 \\
\hline & Price & & & & & & & & \\
\hline & China & -1 & -1 & -1 & -3 & 2 & 5 & 8 & 5 \\
\hline & Japan & 0 & 0 & -1 & -1 & 0 & -1 & -1 & -3 \\
\hline \multirow{10}{*}{ Plywood } & \multicolumn{2}{|c|}{ Consumption } & & & & & & & \\
\hline & China & -4 & -8 & -12 & -16 & -4 & -8 & -12 & -16 \\
\hline & \multicolumn{2}{|c|}{ Production } & & & & & & & \\
\hline & \multicolumn{2}{|c|}{ China $\quad-3$} & -7 & -11 & -15 & -2 & -6 & -11 & -15 \\
\hline & Japan & 6 & 21 & 62 & 135 & 8 & 29 & 60 & 133 \\
\hline & Net trade & & & & & & & & \\
\hline & China & 55 & -75 & -33 & -25 & 69 & -94 & -41 & -31 \\
\hline & $\begin{array}{l}\text { Japan } \\
\text { Price }\end{array}$ & -2 & -11 & -34 & -52 & -3 & -15 & -33 & -51 \\
\hline & China & -1 & -1 & -1 & -2 & -1 & -1 & -1 & -2 \\
\hline & Japan & 0 & 0 & -1 & -3 & 0 & -1 & -1 & -3 \\
\hline & Consumpt & ption & & & & & & & \\
\hline & China & -5 & -10 & -15 & -20 & -7 & -13 & -20 & -25 \\
\hline & Japan & 0 & 0 & 0 & 1 & 0 & 0 & 0 & 1 \\
\hline & Productio & & & & & & & & \\
\hline & China & -6 & -12 & -17 & -23 & -7 & -15 & -23 & -29 \\
\hline Particle & Japan & 2 & 1 & 1 & 1 & 2 & 1 & 1 & 1 \\
\hline & Net trade & & 0 & & & 0 & 0 & 0 & \\
\hline & China & 0 & 0 & 0 & 0 & 0 & 0 & 0 & $\begin{array}{r}0 \\
-12\end{array}$ \\
\hline & Price & -12 & & & & & & & \\
\hline & China & -1 & -1 & -2 & -3 & 1 & 2 & 4 & 4 \\
\hline & Japan & 0 & -1 & -1 & -2 & 0 & -1 & -1 & -2 \\
\hline & Consumpt & ption & & & & & & & \\
\hline & China & -4 & -8 & -12 & -15 & -8 & -15 & -23 & -29 \\
\hline & Japan & 0 & 1 & 1 & 2 & 0 & 1 & 1 & 2 \\
\hline & Productio & & & & & & & & \\
\hline & China & -4 & -9 & -13 & -17 & -8 & -17 & -26 & -33 \\
\hline Fiberboard & Japan & 0 & 1 & 1 & 2 & 0 & 1 & 1 & 2 \\
\hline & $\begin{array}{l}\text { Net trade } \\
\text { China }\end{array}$ & 0 & 0 & 0 & -3 & 0 & 0 & 0 & 0 \\
\hline & Japan & 0 & 0 & 0 & 0 & 0 & 0 & 0 & 0 \\
\hline & Price & & & & & & & & \\
\hline & China & -1 & -1 & -1 & -2 & 2 & 5 & 7 & 9 \\
\hline & Japan & 0 & -1 & -2 & -3 & -1 & -1 & -1 & -3 \\
\hline
\end{tabular}

coincides with its projections of lower decreasing rate of forest area, which is reasonable because production of industrial roundwood is one of the main reasons of deforestation in Africa (Morikawa, 1996). FAO (2009) assumes that "forest loss is likely to continue at current rates,"

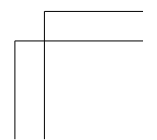


while the GFPM uses a modified forest area change scenario from the IPCC climate-change scenarios (Raunikar et al., 2010), showing that forest area in Africa decreases at a slower rate in the next 20 years. The GFPM results show that the consumption of sawnwood and panel products in Africa would increase, but they would be sourced by import or by a slight increase in production. The GFPM results show that China would continue to rely on foreign raw materials, contributing to increases in Asian and in world consumption and world prices of forest products. Lower GDP growth for China could lead to lower world consumption and lower prices of forest products. Increases in manufacturing costs in China could lead to serious decreases in consumption in China. As China's net trade decreased, caused by a decrease in consumption, the competitive relationship between three East Asian countries - China, Japan and Korea - would be clear of the trends in changes in consumption, production, trade and prices. It was found that if economic growth in China decreased, Japan, Korea, Oceania and Africa might have a chance to consume more forest products by taking advantage of lower prices and their own (abundant) forest resources.

The comparison between actual data and projected data has been discussed in previous research, such as Buongiorno et al. (2003) and Turner et al. (2008). As for the accuracy of GFPM projections, uncertainty exists in "(1) the GFPM structure and parameter estimates (demand and supply elasticities, input-output coefficients, etc.); (2) the model base-year data; and (3) the exogenous assumptions used to make projections" (Turner et al., 2008).

\section{Aknowledgement}

This research was supported and aided financially by the Forestry and Forest Products Research Institute (FFPRI), Research Grant \#200806 
of the FFPRI, and the New Zealand Forest Research Institute Ltd. (trading as Scion).

\section{References}

Buongiorno, J., Zhu, S., Zhang, D., Turner, J.A. and Tomberlin, D. (2003) The Global Forest Products Model: Structure, Estimation and Applications, Academic Press, San Diego, pp.301.

Buongiorno, J. (2010) GFPM Software and Manual, <http://fwe.wisc. edu/facstaff/Buongiorno/book/GFPM.htm> (Accessed 2 June 2010)

FAO (2009) State of the world's forests 2009, <ftp://ftp.fao.org/ docrep/fao/011/i0350e/i0350e.pdf $>$ (Accessed 24 July 2009).

FAO (2010) FAOSTAT, <http://faostat.fao.org/site/626/default.aspx \#ancor $>$ (Accessed 12 February 2010).

Li, R., Buongiorno J., Turner J.A., Zhu S. and Prestemon J. (2008) Long-term effects of eliminating illegal logging on the world forest industries, trade, and inventory, Forest Pol. Econ. 10: 480-490

Michinaka, T., Tachibana, S. and Turner, J.A. (2010) Estimating Price and GDP Elasticities of Demand for Sawnwood: cluster analysis used as a tool in grouping, J. Forest Econ. 56 (3): 29-36.

Morikawa, Y. (1996) Mechanism of deforestation in tropical forests, Deforestation in Tropical Forests (in Japanese), Earth Environment Department, Environment Agency, Chuohoki Publishing Co. Ltd.: $19-24$.

Raunikar R., Buongiorno J., Turner J.A. and Zhu S. (2010) Global outlook for wood and forests with the bioenergy demand implied by scenarios of the Intergovernmental Panel on Climate Change, Forest Pol. Econ. 12 (1): 48-56.

Samuelson, P.A. (1952) Spatial price equilibrium and linear programming. Amer. Econ. Rev. 42: 283-303. 
State Forestry Administration (SFA, China). (2010) Statistics of Forest Resources (In Chinese), Various editions, China Forestry Publishing House, Bejing.

Turner, J.A., Buongiorno, J. and Zhu, S. (2006) An economic model of international wood supply, forest stock and forest area change, Scand. J. Forest Res. 21: 73-86.

Turner, J.A., Buongiorno, J., Katz, A. and Zhu, S. (2008) Implications of the Russian softwood log export tax for the Russian and global wood products sectors, Scand. J. Forest Res. 23(2): 154-166.

U.S. Energy Information Administration (2010) International Energy Outlook 2010, <http://www.eia.doe.gov/oiaf/ieo/> (Accessed 6 June 2010).

World Bank (2009) World Development Indicators/Worldview, People, Environment, Economy, States and Markets, Global Links. Washington, DC. <http://data.worldbank.org/data-catalog/worlddevelopment-indicators/> (Accessed 20 June 2010).

World Trade Atlas (WTA) (2010) World Trade Atlas Trade Information System, Global Trade Information Services, Inc., Columbia, SC.

Zhu, S., Tomberlin D. and Buongiorno J. (1998) Global forest products consumption, production, trade and prices: global forest products model projections to 2010, <http://www.fao.org/DOCREP/003/ X1607E/X1607E00.HTM > (Accessed 20 June 2010).

Zhu, S., Buongiorno, J., Turner, J. and Raunikar, R. (2010) Using the Global Forest Products Model (GFPM version 2009) Staff Paper Series \#66, Department of Forest and Wildlife Ecology, University of Wisconsin-Madison. 


\title{
中国の変化が日本及び他の主要な国の森林セクター に与える 影響の解明
}

\author{
道中哲也・立花 敏・ジェームス・ターナー・堀 靖人・ \\ 平野悠一郎
}

要約:

本研究は、中国の国内市場および林産物貿易の変動により森林セクターの影 響を分析することを目的とする。本研究ではまず、クラスター分析とパネル 分析手法を用いて、7つの林産物の需要の価格と所得の弾力性を推定した。 一人当たりの所得、一人当たりの林産物消費量、光の国の森林率の水準に基

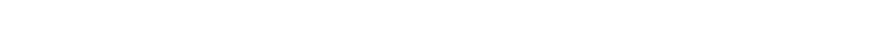
パネル分析を行った。需要の弾性值と GDP 成長率などの他の外生变数を用 いて、グローバル林産物モデル (GFPM) を通じて、2030 年までのグロー バル森林セクターをシミュレーションした。GFPM モデルは 180 ヶ国お よび 14 の林産物を取扱う動学的経済均衡モデルである。GFPM のシミュ レーション結果によると、中国は輸入原料に頼り続けており、また、この依 頼によってアジア及び世界の林産物の消費と価格の上昇を引き起こす。中国 の GDP 成長率が低くすれば、世界の林産物の消費量と価格が低くなる。同 時に、日本や韓国といった原料輸入国が中国の輸入減少による低価格のきっ かけで、輸入が増える。また、中国の林産物の製造コストが増えると、中 国の林産物の消費に大きな影響を与えるが、日本や韓国といった輸入国に 大きな影響が見られなくて、アフリカやオセアニアといった輸出地域に、消 費を増やす、輸出を減少することを引き起こすことが、GFPM の結果でわ かった。

キーワード：グローバル林産物モデル (GFPM)、長期見通し、クラスター分析、林産物、 中国、日本 